\title{
Benchmarking a vybrané oblasti jeho použití
}

\author{
Martin Ambros ${ }^{1}$, Jana Kleinová ${ }^{1}$ \\ 1 Západočeská univerzita v Plzni, Fakulta strojní, Katedra průmyslového inženýrství a \\ managementu \\ Univerzitní 8, 306 14, Plzeň, Česká republika \\ ambros@kvp.zcu.cz \\ kleinova@kpv.zcu.cz
}

\begin{abstract}
Anotace: Článek pojednává o benchmarkingu a vybraných oblastech jeho použití. V první části je teoreticky uvedena historie benchmarkingu, definice základních pojmů a následně popis jednotlivých typů benchmarkingu spolu $s$ jeho prínosy. $V$ další části je popsáno použití benchmarkingu $v$ environmentálním managementu, zdravotnictví a stavitelství. Poslední část pojednává o stavu benchmarkingu v České republice.
\end{abstract}

\section{1 Úvod}

$\checkmark$ současném turbulentním světě se prakticky všechny společnosti bez ohledu na odvětví a velikost musí vyrovnávat s tlaky na zlepšování, inovace a změny - od těch drobných až po radikální, typu kompletní změny organizačních struktur. To vše díky neustálým změnám ve společnosti a obrovské konkurenčnosti na současném globalizovaném trhu. Společnosti jsou tak tlačeny stále více hledat způsoby, jak snižovat své náklady. Existuje mnoho konceptů či nástrojů, jak zvyšovat svoji efektivnost a snižovat náklady - např. Six Sigma či Lean production apod. Jedním z nástrojů je i benchmarking, který je ve světě poměrně rozšířen. Bohužel $v$ České republice není až tak znám, povětšinou díky nedostatku české odborné literatury.

\section{Benchmarking}

Benchmarking aktivity jsou známy již od prvopočátku lidstva. $V$ dobách, kdy lidé žili $v$ jeskyni a živili se lovem zvěře, obyvatelé jeskyní vypozorovali, že někteří lovci byli úspěšnější než ostatní. Zjistit, proč jsou tito lovci tak úspěšní a následně převzít jejich procesy, nástroje či techniky mohlo být záležitostí vlastního přežití. Snaha o identifikování nejlepších praktik a jejich následná implementace se historicky vyvijela samovolně. Milník nastal v roce 1989, kdy vyšla kniha Roberta Campa Benchmarking: The Search for Industry Best Practices That Lead to Superior Performance. Tato publikace formalizovala oblast benchmarkingu a dala ji své jméno. Robert Camp je všeobecně považován za zakládajícího člena benchmarkingu jako nástroje efektivního ř́izení. [1] 
Víceméně veškeré formy a typy benchmarkingu vycházejí ze společného základu: Jestliže se společnost rozhodla ve vlastním prostředí přistoupit ke změnám a zlepšování, proč se nepoučit u někoho, kdo s něčím podobným již má pozitivní zkušenosti a je ve zkoumané oblasti dále? Zjednodušeně, benchmarking je způsob učení se z lepší reality, než je realita vlastní. [2]

\subsection{Historie}

Průkopníkem benchmarkingu je společnost Xerox, která se $v 70$. letech potýkala se značnými ekonomickými problémy, jelikož její výrobky kopírovací techniky začaly být vytlačovány japonskými konkurenty. Při prvních komparativních studiích firmy Xerox vyšlo najevo, že výrobní náklady Xeroxu jsou na úrovni prodejních cen japonských konkurentů prì srovnatelné kvalitě. Při analýze prríčin vysokých nákladů se ukázalo, že jednou z hlavních možných zlepšení je oblast skladového hospodářství. Bylo zjištěno, že $v$ tehdejší době byla na špici společnost L. L. Bean, a tak ji Xerox požádal o první hlubší srovnávací studii ohledně skladového hospodářství. Tato studie následně dopadla velmi dobře. Všeobecně se touto studií datuje vznik moderního benchmarkingu. [2]

\subsection{Definice, základní pojmy}

Výchozím pojmem je pojem benchmark. Tento pojem je chápán jako měřítko, ukazatel výkonnosti, jehož úrovní se společnost hodlá inspirovat. Lze ho chápat jako lat'ku, kterou si společnost sama nastaví, aby se ji pokusila dále překonat. Například u nákladů, produktivity či průběžně doby výroby daného produktu. Benchmarky mohou sloužit taktéž jako kritéria optimalizace - za předpokladu, kdy se chce společnost porovnávat s absolutní špičkou. [2]

Benchmarking není normovanou metodou, a tak existuje mnoho jeho definic. Americké centrum pro produktivitu a jakost (APQC), které je považováno na americkém kontinentě za klíčovou organizaci zabývající se rozvojem přístupů, metod a realizací benchmarkingu, definuje benchmarking následovně: „Benchmarking je proces identifikování, poznání, prevzetí a prizpůsobení vynikající praxe a procesů jakékoliv organizace na světě, jenž pomáhá zlepšovat vlastní výkonnost." [2]

$\mathrm{V}$ souvislosti s benchmarkingem se lze setkat i s tzv. benchlearningem, který je definován jako „Způsob, jak propojit zdokonalování systému rízení a výcvik zaměstnancư s potřebami firmy, a tím zajistit jejich bezprostřední užitečnost." Což Ize zjednodušeně uvést jako trvale a systematicky porovnávat a měřit produkty a služby poskytované danou společností s těmi, které jsou lídry $v$ dané oblasti. Zatímco benchmarking srovnává a přebírá současné postupy nejlepší praxe, benchlearning znamená, že se společnost neustále učí a vylepšuje další osvědčené postupy. [2] 


\subsection{Typy benchmarkingu}

V závislosti na charakteru zvoleného objektu benchmarkingových zkoumání se rozlišuji tři typy benchmarkingu, viz. následující obrázek 1.

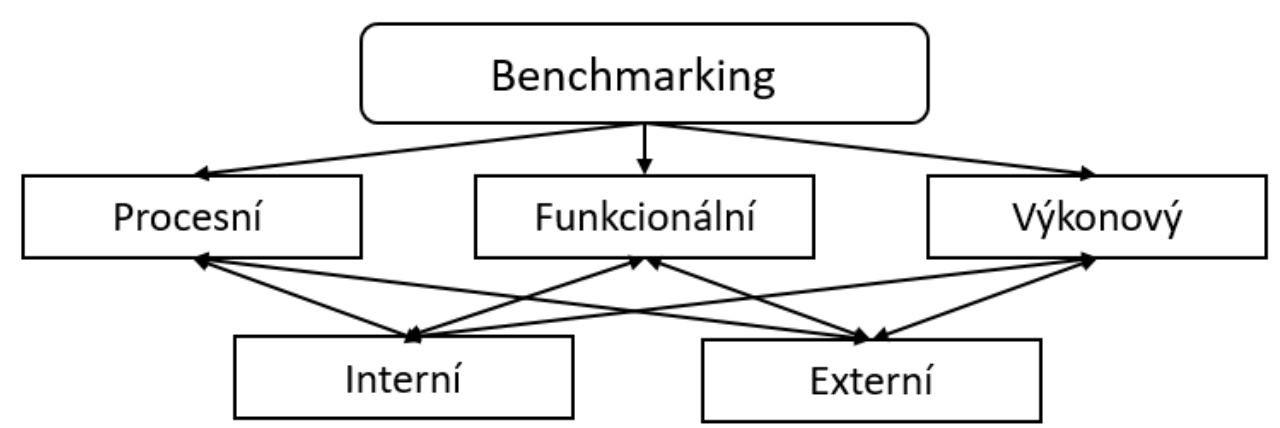

Obrázek 1 - Typy benchmarkingu

1. Benchmarking výkonový - orientován na přímé porovnání a měření různých výkonových parametrů. Př́kladem může být výkon motoru, výkon pracovníka či výkon určité montážní linky. Výsledkem výkonového benchmarkingu je nejčastěji srovnání klíčových ukazatelů výkonnosti či parametrů srovnatelných produktů. [2]

2. Benchmarking funkcionální - při tomto benchmarkingu se porovnává jedna či více funkcí určité organizace. Nevýhodou může být, že většinou vyžaduje poměrně vysoké finanční zdroje. [2]

3. Benchmarking procesní - někdy označován jako generický, je souborem aktivit, kde je centrem pozornosti porovnávání a měření konkrétního procesu organizace. Tento typ je považován za nejúčinnější. Podle studií může procesní benchmarking pomoci vyřešit 90 \% všech úzkých a problémových míst v organizaci. [2]

Benchmarking Ize dělit taktéž na externí či interní. Na tomto dělení se shodne vesměs celá odborná komunita.

- Interní benchmarking - realizován $v$ rámci jedné společnosti mezi zvolenými organizačními jednotkami, jež zabezpečuji stejné, nebo podobné produkty, procesy a funkce. Hlavním cílem zde bývá potřeba nalezení dočasně nejlepšího vnitřního standardu výkonnosti.

- Externí benchmarking - soubor činností, $v$ jejichž rámci je partnerem pro srovnávání a měření jiná organizace. Problémem ovšem může být vyhledat vhodného externího partnera, zejména v případě, jedná-li se o prímého konkurenta. [2]

- Význam a pozitivní efekty benchmarkingu byly natolik zřejmé, že je tvưrci nejrůznějších norem zařadili do svých modelů. $V$ současnosti tak tuto metodu bud' vyžadují či doporučují. Ze všech modelů je vhodné zmínit tři hlavní a to [2]:

- Model systému managementu podle normy ISO 9004 
- Model pro excelentní výkonnost v rámci Národního programu jakosti M. Baldrige

- Model excelence doporučovaný Evropskou nadací pro management jakosti (EFQM)

\subsection{Důsledky a prínosy benchmarkingu}

Pro vyjádření přínosů a efektů benchmarkingu je využit výzkum realizovaný již zmíněným Americkým centrem pro produktivitu a jakost (APQC). Výzkum obsáhl téměř tisíc organizací na americkém kontinentě, které měli praktickou zkušenost $s$ benchmarkingem. Drtivá většina organizací viděla největší pozitivní efekt $v$ procesech poučení se $z$ lepší reality, zatímco prímé ekonomické efekty zmiňovalo pouze $4 \%$ organizací. Průměrná doba trvání benchmarkingového projektu byla přibližně šest měsíců s vynaložením zdrojů $v$ hodnotě cca 50000 USD. Členové benchmarkingového týmu byli převážně manažeři střední úrovně řízení a časově jim práce na benchmarkingových projektech ukrojila $25 \%$ jejich pracovního času. Průměrná návratnost vložených prostředků je asi pětinásobkem vynaložených zdrojů, zejména zásluhou redukce nákladů na procesy, zvýšení prodejů, vyšší míry spokojenosti zaměstnanců apod. [2]

Dle jiného výzkumu prováděného $v$ britských organizacích vyšly najevo následující skutečnosti:

- $56 \%$ respondentů uvedlo, že benchmarking prisispěl $v$ jejich organizacích ke zvýšení produktivity.

- $75 \%$ respondentů by doporučilo aplikovat benchmarking i těm organizacím, které jej zatím neprováděly.

- $77 \%$ respondentů uvedlo, že právě benchmarking je dovedl k zásadním inovacím a změnám. [2]

$\checkmark$ roce 2009 byl konzultační společností Bain realizován výzkum (Bain and Comany's Management Tools and Trends) do kterého bylo zapojeno více než 1400 organizací z celého světa. Výstupem tohoto výzkumu je mimo jiné tvrzení, že benchmarking je v současnosti chápán jako vůbec nejúčinnější př́stup ke snižování nákladů. [2]

\section{Benchmarking v environmentálním managementu}

Podnětem $k$ použití benchmarkingu $v$ environmentálním managementu je zejména norma ISO 14000, charakterizující standardy zaměřené na management životního prostředí $v$ pracovním prostředí organizací. Společnosti začali využívat environmentální benchmarking za účelem identifikace ekologicky účinných řešení. Benchmarking se tak stal prostředkem, jak tato řešení nalézt. [5]

Environmentální benchmarking může být definován jako kontinuální proces měření vlastní ekologické výkonnosti systémů, procesů a produktů ve 
společnosti a porovnávání je s konkurenčními úspěšnými společnostmi. Cílem tohoto porovnávání je převzít nové myšlenky a praktiky a implementovat je do vlastní společnosti za účelem zvýšení vlastní ekologické výkonnosti. [5]

Benchmarking můžeme uplatnit ke zlepšení environmentálního managementu jako celku či určité jeho části. Mưže to být například zacházení s energií, prevence, lepší efektivnost hospodaření s odpady či šetrné zacházení s obalovými a jinými prostředky. Hlavním použitím benchmarkingu jsou tyto dvě oblasti:

- Porovnání výkonnosti vlastní společnosti ve smyslu environmentálního managementu, jejích funkcí a procesů s podobnou organizací.

- Identifikovat prvky, které způsobují rozdíl mezi porovnávanými entitami a nalézt důvody, která zapř́íčinuuji horší výkon. [5]

Environmentální benchmarking je velmi efektivní nástroj, který přispívá ke zvýšení úrovně environmentálního managementu. Vzhledem k současnému trendu ekologičnosti a použíání nejrůznější eko-šetrných materiálu se dá očekávat čím dál vyšší zájem o benchmarking v této oblasti. [5]

\section{$4 \quad$ Benchmarking ve stavebnictví}

V oblasti stavebnictví se benchmarking začal rozvíjet zejména ke konci minulého století. Značným impulsem byla publikace Rethinking Construction, sepsaná Sirem Johnem Eganem, od roku 1980 do 1990 známému široké veřejnosti jako ředitel Jaguaru. Podnětem k sepsání publikace byla snaha o radikální zlepšení procesů mající za cíl vyšší kvalitu, bezpečnost, rychlost stavby, menší variabilitu dílů a samožrejmě nižší cenu. To vše za účelem zvýšení profitability. Benchmarking je zde chápán jako základní stavební kámen $k$ docílení výše zmíněného úsilí. Benchmarking hraje značnou roli jak $v$ soukromém, tak veřejném sektoru. Ve veřejném sektoru je převážně tažen vládou a národními institucemi. [3] [7]

V oblasti stavitelství se pořádají různé workshopy za účelem nalezení a sdílení znalostí, jak „věci dělat lépe“. Na těchto workshopech se scházejí odborníci a sdílejí své znalosti. Příkladem může být workshop pořádaný asociací Construction Productivity Network. Napríklad mezi lety 1998 a 2000 se konalo 30 setkání zabývajících se benchmarkingem, kde se sešlo více než 1300 odborníků, kteří diskutovali a sdíleli své znalosti a zkušenosti mezi sebou. [3]

Benchmarking je nástroj, který může pomoci stavebním firmám zjistit jejich vlastní výkonnost ve srovnání $s$ jejich konkurenty za účelem implementace změn, které jim zajistí dosažení nejvyšší možné úrovně. V konkrétním případě např. společnost Taywood Engineering Ltd používá benchmarking ve svých projektech za účelem identifikace strategie mající za cíl dosažení nulových defektů ve stavitelství, včetně principu tzv. „Zero defect culture“ a množství různých nástrojů pro zvyšování kvality jako např. stop tlačítko určené jako prevence proti chybám v procesu. [7] 


\section{$5 \quad$ Benchmarking ve zdravotnictví}

Benchmarking nachází své uplatnění rovněž v nevýrobní sféře, např. ve zdravotnictví. V roce 2006 vyšel v USA obsáhlý report s názvem Press Ganey 2006 Health Care Satisfaction Report, ve kterém se jako jeden z hlavních závěrů ukázal obrovský rozdíl mezi spokojeností pacientů jednotlivých nemocnic. Benchmarking poskytuje nástroj, jak tento rozdíl efektivně snižovat. To vše pomocí učení se, jak nejlépe hodnocené zdravotnické instituce dosahují tohoto hodnocení, potažmo výkonu. Nemocnice se slabým hodnocením se mohou následně rozhodnout, kterým směrem a jak zlepší svoje procesy a potažmo svoji výkonnost či hodnocení. V zásadě platí rčení „převezmi to nejlepší, co funguje $v$ ostatních oborech a implementuj ho do zdravotnictví. [1]

Benchmarking ve snaze o zvyšování vlastní výkonnosti je ve zdravotnictví používán ve více směrech. Používá se pro porovnání interního a externího výkonu, identifikování nejlepších praktik a $\mathrm{k}$ odhalování příležitostí pro zlepšení. Nezávisle na tom, jak organizace používá benchmarking, její cíl by měl být pořád stejný, tj. zlepšení vlastního výkonu. [4]

Organizace mohou použít benchmarking pro jakoukoliv oblast - tj. např́klad pro počáteční spuštění nějakého specifického programu či $k$ měření finálních výstupů určitého procesu. Benchmarking může být velmi vhodným nástrojem zejména pro zajištění splnění legislativních regulí, kterých je ve zdravotnictví mnoho. PIno lidí považuje benchmarking jen za nástroj pro použití $k$ individuálním prípadům, jako např. k snížení míry úmrtnosti, infekčnosti či spokojenosti pacientů. Ve skutečnosti benchmarking přináší př́ležitosti pro vyřešení komplexnějších problémů, jako je provádění lepší péče či získání konkurenční výhody oproti ostatním zdravotnickým zařízením. [4]

$\checkmark$ současnosti mnoho zdravotnických zařízení v USA príjalo benchmarking jako součást jejich snahy o zlepšení výkonnosti. Je neoddiskutovatelným faktem, že benchmarking bude hrát čím dále více větší roli zejména díky již zmíněným legislativním a akreditačním požadavkům. Benchmarking se pomalu ale jistě dostává $z$ doporučované metody na metodu povinnou, která ukazuje výkon organizace ve specifických oblastech a shodu s legislativními požadavky, jejichž nesplnění ústí ve značné finanční škody. V USA existuje organizace Joint Commision International $(\mathrm{JCl})$, která poskytuje návod a podporu benchmarkingovým projektům skrze její vlastní standardy. Benchmarking je možno použít $v$ jakémkoli typu zdravotnického zařízení kdekoli na světě, musí být ovšem přijat managementem daného zařízení a stát se jeho součástí, firemní kulturou. [4]

\section{Benchmarking $\mathbf{v}$ České republice}

$\checkmark$ české republice došlo $\mathrm{k}$ rozvoji benchmarkingu převážně po revoluci $v$ roce 1989. Tento nástroj se postupně dostává čím dál více do povědomí soukromých a veřejných institucí. Prostřednictvím státu je benchmarking 
uplatňován zejména ve formě agregovaných statistických dat sloužících $\mathrm{k}$ porovnání určitých subjektů. $V$ České republice pưsobí dvě veřejné instituce, které se zabývají benchmarkingem. Jedná se o Českou společnost pro jakost (ČSJ) a Czechlnvest. [5]. ČSJ přináší možnost školení a kurzů benchmarkingu a dále poskytuje mezinárodní srovnání výkonnosti malých a středních podniků do 250 zaměstnanců pomocí Benchmark indexu. Tento index je založen na metodice indikátorového benchmarkingu neboli porovnání číselných údajů výkonnosti. Výsledná analytická zpráva, kterou generuje systém dle vybraných kritérií, obsahuje hodnocení organizace ve srovnání s nejlepšími v Evropě i ve světě a je strukturována podle metodiky Balanced Scorecard. [8]

$\mathrm{Na}$ začátku tisíciletí agentura Czechlnvest spustila vlastní pilotní projekt Benchmark indexu $\vee$ ČR. Do tohoto projektu byli zapojeni někteří členové Moravskoslezského strojírenského klastru. Cílem bylo pomoci organizacím zvýšit konkurenceschopnost a ziskovost $v$ rámci sektoru, sítě nebo klastru. Projekt běžel mezi lety 2003-2004 a ze zpětné vazby účastníků vyplynulo, že společnosti shledaly značný přínos tohoto projektu. Zejména vyjádřily názor, že projekt přinesl nové pohledy a poukázal na oblasti pro zlepšování. V neposlední řadě projevily zájem na pokračování $v$ benchmarkingových aktivitách. [9]

Benchmarking se taktéž začal uplatňovat $v$ oblasti veřejné správy zhruba od roku 2000. Počátky jsou spojeny převážně s účelově pojatými projekty spolufinancovanými $z$ fondů EU. Benchmarking je $v$ největší míře implementován $v$ orgánech územní samosprávy - úřadů ORP. Vše bylo započato $v$ roce 2000 realizací tzv. pilotního benchmarkingového projektu Cena a výkon, do kterého bylo zapojeno šest magistrátů statutárních měst. [6]

Na základě př́nosných výsledků projektu byl v roce 2003 zahájen projekt s názvem Benchmarking $v$ oblasti rozšířené působnosti obcí 3 . typu. Do projektu bylo zahrnuto 48 obcí s rozšířenou působností, jehož výstupem bylo zejména porovnání výkonů v 29 agendách obce s rozšířenou působností. [6]

Tato spolupráce zmíněných obcí následně pokračovala $v$ rámci nově vzniklého neformálního sdružení pod názvem Benchmarkingová iniciativa 2005 (BI 2005). Tato iniciativa trvá až dosud a postupně se do ní zapojuje více a více úřadů. Cílem benchmarkingové iniciativy je zvyšovat výkonnost a kvalitu činností úřadů prostřednictvím benchmarkingu ve vybraných oblastech přenesená a samostatné působnosti obce. Úřady ORP v rámci BI 2005 realizují benchmarking na základě specifického systému sdílení dobré praxe a porovnávání stanovených ukazatelů v 53 agendách samostatné a přenesené pưsobnosti ORP. [6]

Co se týče hodnocení spolupráce, tak dle výsledků z dotazníkového šetření z období roku 2005 až 2010 vyplynulo, že využití benchmarkingu má pozitivní vliv na kvalitu rozhodování managementu úřadu a následně produktivitu a výkonnost zaměstnanců i konkrétních úseků úřadu. Nejčastěji jsou změny prováděny $v$ oblastech rozpočtování, investičních zakázek, personální 
agendy, provozních výdajů (úklid, autoprovoz, poštovné ...) či procesů správního rízení. Co se týče efektů prováděných změn, převládají ty, které nelze moc dobře finančně vyčíslit. Jedná se např. o zkrácení doby správního řízení, zlepšování komunikace a hodnocení zaměstnanců úřadů ORP. Obecně Ize říci, že $z$ výstupu benchmarkingu vyplívají změny $v$ organizační struktuře a postupech úřadů ORP, které mají ve svém důsledku příznivý vliv na produktivitu práce zaměstnanců a konkrétních úseků. [6]

\section{Závěr}

$\mathrm{Na}$ základě podrobné analýzy prínosů benchmarkingu bylo dokázáno, že benchmarking dokáže téměř v $60 \%$ prípadů zvyšovat produktivitu dané organizace. Jedná se o nástroj, který pravděpodobně čeká stále větší rozšíření nejen $v$ zahraniční, ale $\mathrm{i} v$ České republice, kde zatím není přiliš využíván. Především díky tomu, že management nemá dostatečné znalosti o možnostech využití benchmarkingu, a to i z důvodu nedostatku odborné literatury. Benchmarking se stále více uplatňuje v různých oblastech, ovšem cílí vždy na stejný záměr, tj. poznání nejlepších praktik a jejich následnou implementaci do vlastní organizace. Benchmarking je také velmi vhodný nástroj pro splnění nejrůznějších legislativních požadavků a nařízení, především v oblasti zdravotnictví.

\section{Poděkování}

Tento článek byl vytvořen za podpory interního grantu Západočeské univerzity číslo projektu je SGS-2018-031 s názvem Optimalizace parametrů udržitelného výrobního systému.

\section{Použitá literatura}

[1] Sower, V., Duffy, J. A., Kohers, G. Benchmarking for Hospitals: Achieving Best-in-class Performance Without Having to Reinvent the Wheel. American Society for Quality, Milwaukee, 2007, 203 s. ISBN 978-0873897228.

[2] Nenadál, J., Vykydal, D., Halfarová, P. Benchmarking - mýty a skutečnost. Management Press, Praha, 2011, 268 s. ISBN 978-80-7261-224-6.

[3] McCabe, S. Benchmarking in Construction. Blackwell Science, 2001, $308 \mathrm{s.}$ ISBN 978-0632055647.

[4] Joint Commission Resources. Benchmarking in health care. Second edition. USA, Joint Commission Resources, 2011. ISBN 978-1-59940-616-9.

[5] Jetmarová, B. Application of benchmarking in enviromental management. Scientific papers of the University of Pardubice, 2010, s. 156165. ISSN 1211 - 555X.

[6] Vrabková, I. Benchmarking a jeho vliv na výkonnost úřadů obcí s rozšiřenou působností. In: Ekonomická revue, 2012, roč. 15, č. 1, s. 41-50. ISSN $1212-$ 395. 
[7] Egan, J. Rethinking Construction. Department of Trade and Industry, UK, London, 1998.

[8] Fousková, K. Benchmarking. [online] Česká společnosti pro jakost, Praha, [cit. 2019-08-12]. Dostupné z: https://www.csq.cz/benchmarking/

[9] Pilotní projekt BenchmarkIndex v ČR. [online] CzechInvest, Praha [cit. 201908-12]. Dostupné z: https://www.czechinvest.org/cz/Homepage/Akce/Pilotniprojekt-Benchmarklndex-v-CR 